\title{
The Potentiality of Non Timber Forest Products. Fruit Availability, Phytochemical Properties of Rosa rubiginosa L. Rose Hips
}

\author{
Gerardo U. Aguirre', Martín Loza1, José Gasquez², María Fusco³ , Angela Sosa ${ }^{3}$, Gladys M. Ciuffo ${ }^{4,5}$, \\ Liliana E. C. Ciuffo ${ }^{1}$ \\ ${ }^{1}$ Ecología y Conservación, Facultad de Química, Bioquímica y Farmacia, Universidad Nacional de San Luis, San Luis, Argentina \\ ${ }^{2}$ UNSL/FQBF/Química Analítica, Ejército de los Andes, San Luis, Argentina \\ ${ }^{3} \mathrm{UNSL} / \mathrm{FQBF} /$ Farmacognosia, Ejército de los Andes, San Luis, Argentina \\ ${ }^{4}$ UNSL/FQBF/Bioquímica Avanzada, Ejército de los Andes, San Luis, Argentina \\ ${ }^{5}$ IMIBIO/CONICET, Ejército de los Andes, San Luis, Argentina \\ Email: eugeciuffo@gmail.com
}

How to cite this paper: Aguirre, G.U., Loza, M., Gasquez, J., Fusco, M., Sosa, A., Ciuffo, G.M. and Ciuffo, L.E.C. (2016) The Potentiality of Non Timber Forest Products. Fruit Availability, Phytochemical Properties of Rosa rubiginosa L. Rose Hips. American Journal of Plant Sciences, 7, 2272-2287. http://dx.doi.org/10.4236/ajps.2016.715200

Received: September 21, 2016

Accepted: November 13, 2016

Published: November 16, 2016

Copyright $\odot 2016$ by authors and Scientific Research Publishing Inc. This work is licensed under the Creative Commons Attribution International License (CC BY 4.0).

http://creativecommons.org/licenses/by/4.0/ (c) (i) Open Access

\begin{abstract}
We evaluated fruit availability, phytochemical characteristics and mineral content of $R$. rubiginosa L. rose hips, at two experimental sites in San Luis province: Potrero de los Funes-El Volcán (PF-V) and Estancia Grande (EG). Plant density was 70 plants/ha $\left(1 \mathrm{ha}=10,000 \mathrm{~m}^{2}\right)$ in PF-V and 50 plants/ha in EG. Fruit availability $\left(D_{F}\right)$ in fresh fruits (FF) was $4.39 \mathrm{~kg}(\mathrm{PF}-\mathrm{V})$ and $3.10 \mathrm{~kg}$ (EG) during March, and decreased during June. Ascorbic acid in FF increased during ripening period, peaking on late April, early May, and diminished $75 \%-85 \%$ in dried fruits. Total soluble solids in FF ranged from 32.55 to $55.20^{\circ}$ Brix. Elements $\mathrm{Ba}, \mathrm{Ca}, \mathrm{Fe}, \mathrm{K}, \mathrm{Zn}$ and $\mathrm{Cu}$, determined by inductively coupled plasma optical emission spectrometry (ICP-OES), were significant for human health. Dried fruits maintain a high level of ascorbic acid, a characteristic added to content of mineral elements, particularly calcium content, providing an important nutritional value to $R$. rubiginosa rose hips.
\end{abstract}

\section{Keywords}

Rosa rubiginosa Rose Hips, Fruit Chemical Contents, Ascorbic Acid, Mineral Elements

\section{Introduction}

Invasion of natural woodland by exotic plant species is recognized as a major threat to biodiversity [1]. Rosa rubiginosa L. is a widespread shrub species, introduced to Argen- 
tina, and widely distributed along the Andean Patagonic region [2] and gradually expands toward the central region of the country.

R. rubiginosa and $R$. moschata are considered non-timber forest products (NTFP) by the Food and Agriculture Organization [3]. Harvest and consumption of plant products from natural forests is known to account for a large proportion of the livelihood of people living close to such habitats [4]. The lack of information on ecology, nutritional, medicinal properties and characteristics of NTFP species, as well as used parts of the plant is the main disadvantage of initiatives intended for use and management of NTFP resources.

According to the United Nations Organization for Food and Agriculture [5], nontimber forest products are goods of biological origin, other than wood derived from forests, other wooded areas and trees outside forests. NTFP are collected in the wild or produced in forest plantations or agroforestry systems. These products mostly from plants are used as food and food additives (edible seeds, mushrooms, fruits, spices, flavorings), fibers, instruments or utensils, resins, gums, and others used for medicinal or cultural purposes, cosmetics. Non timber forest products have been essential for subsistence and commercial activities all around the world.

Like other species, $R$. rubiginosa has been used by the Mapuche rural communities located in Neuquén province and suburban areas of Bariloche (Río Negro, Argentina), considered as a useful exotic plant for those families who have dietary restrictions or limited access to medicines [6].

Rose hips of $R$. rubiginosa are extensively used worldwide in food preparation and traditional medicine, because of the high content of vitamin $C$, mineral content and its potential antioxidant capability. Edible rose hips contain approximately $500-2200$ $\mathrm{mg} / 100 \mathrm{~g}$ in fresh fruit of vitamin C [7] [8] [9] [10], riboflavin, pectins, nicotinic and malic acids, carotenes. Rose hips are used for tea, jams and also as a pigment. It also contains minerals such as potassium, calcium, sodium, iron, magnesium and phosphorus [11]. Seeds mainly contain up to $8 \%$ of the oil which comprises oleic, linoleic, linolenic acid, and trans retinoic acid [12]. The rosehip seed's oil is used in the cosmetic industry because it possesses the property to accelerate regeneration and healing of damaged tissues [13] and because of its antioxidant activity [12].

In Argentina, the availability of rose hip fruits was assessed in the Neuquén province in order to contribute to making a decision for the promotion of industrial exploitation of wild populations of this species [2] [14]. On the other hand, while this introduced species is considered an invasive weed and undesired in protected areas of Patagonia, in suburban areas of Bariloche it is recommended for sustainable development and conservation of wildlife because its commercial value [15].

Damascos et al. [16] informed that the mineral content of fruits from Patagonia was similar to values reported for species of temperate and tropical zone.

For the province of San Luis only a few studies have been conducted at the time. Genetic variation within and among populations of $R$. rubiginosa was assessed in samples from San Luis and Neuquén provinces, by using of RAPDs (Random Amplification of 
Polymorphic DNA) markers [17] [18], and genetic differentiation of the introduced species was studied [19].

The aim of the present study was to evaluate rose hip fruits from $R$. rubiginosa, a species of medicinal use and interest for sustainable use as NTFP, as a source of vitamins and minerals. This study was conducted using an approach from applied ecology to estimate fruit availability, and phytochemical and analytical procedures to assess the content of vitamin C, soluble solids and mineral elements in fruits of $R$. rubiginosa in native forests of San Luis.

\section{Materials and Methods}

\subsection{Study Area}

The study area falls within the Dry Chaco Ecoregion, subregion of Chaco Serrano in the province of San Luis, Argentina.

The study area belongs to the Dry Chaco Ecoregion, subregion of Chaco Serrano in the province of San Luis, Argentina. The Chaco Serrano constitutes most of the western boundary of the Dry Chaco region. It is conformed by elements of the Sierras Pampeanas and lower lands in the Sierras Subandinas. At the West limit of the semiarid Chaco, the hills constitute an orographic barrier for the wet winds from the East, a fact that causes higher precipitations on the eastern hillside while dry climates developed on the western side of the hilly areas. This fact, together with the thermic variation associated to the altitude might establish particular climate conditions which determine vegetation development [20].

The area under study has been subject of anthropic action for different uses: deforestation, over grazing, fire regimes, settlement and tourism use. All these processes favor the degradation of the environment. The altitudinal gradient mountain forest comprises: forest Prosopis flexuosa (850 to $920 \mathrm{~m}$ a.s.1.), then the forest Lithraea molleoides (950 to $1300 \mathrm{~m}$ a.s.l.) including communities of streams, riparian, river beds and shrubs slope. At higher altitudes, the forest is replaced by grasslands or grass steppes predominant species of Stipa sp. and Festuca hieronymi [21].

\subsection{Experimental Sites}

Fruit sampling of $R$. rubiginosa was carried out at two experimental sites, situated on the Eastern slope of the southern end of the Sierra de San Luis, with the following characteristics:

Experimental site 1: is situated between the towns of Potrero de los Funes and El

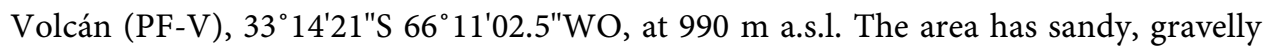
soils, with gravel, but also found some loam with organic matter content. Average annual precipitation totals about $700 \mathrm{~mm}$ or higher and its rains more frequently during the summer. Higher peaks, above $1400 \mathrm{~m}$ a.s.l. see occasional snow in winter. The described rainfall regime renders this area a humid to subhumid zone in San Luis province, allowing species with higher humidity requirements to growth.

Experimental site 2: it is located at the town of Estancia Grande (EG), 33 $13^{\circ} 32^{\prime \prime} \mathrm{S}$ 
$66^{\circ} 10^{\prime} 35^{\prime \prime} \mathrm{WO}$, at $1020 \mathrm{~m}$ a.s.l. The area is one of the most humid in the whole province, where average annual precipitation is superior to $700 \mathrm{~mm}$. In this area, the climate is highly variable and presents major seasonal changes. However, the weather has very strong seasonal characteristics, $80 \%$ of torrential rains concentrated between October and March, reaching intensities of up to $80 \mathrm{~mm} / \mathrm{ha}$. The average annual temperature is $17^{\circ} \mathrm{C}$ with highs exceeding $35^{\circ} \mathrm{C}$ in summer and minimum below $0^{\circ} \mathrm{C}$ in winter. The soil, characteristics of Loesoid Plain, consists of three main geomorphological units: loesoid hills, valleys and streams [22]. The soils of the area enable the development of agroforestry activities, leading to deforestation of natural forests in the lower parts of the basin, with the consequent increase of erosive susceptibility.

\subsection{Description of Rosa rubiginosa L.}

Rosa rubiginosa (Rosa eglanteria L.) belongs to the Rosaceae family, Rosa genous, vulgar name "rosa mosqueta". It is an introduced species in Argentina and it growths as an erect or scrambling shrub, of variable height (up to $2.5 \mathrm{~m}$ tall), frequently in groups of several plants of about $3 \mathrm{~m}$ diameter. The numerous branches present abundant prickles. The crushed foliage has a sweet apple-like fragrance, a distinctive character for R. rubiginosa [23].

\subsection{Field Sampling of Rose Hip Fruits}

R. rubiginosa was sampled from two experimental sites as pointed out above, during year 2009, to estimate fruit availability and plant density. At each experimental site we selected an area of $50 \times 100 \mathrm{~m}(1 / 2 \mathrm{ha})$ as representative of the native woodland. Separately, rose hip fruits were collected to evaluate the content of minerals elements.

To estimate fruit availability, rose hips from three plants were collected at each experimental site, considering a minimum plot size of $1 \mathrm{~m}^{2}$ surface. Harvests were conducted at the beginning and final stages of the maturation period (March and June). Two plots were sampled for each individual plant, by cutting the rose hip fruits with scissors and collecting them on a plastic underneath the plant. Wet weight was determined immediately on arrival to the lab and an aliquot was kept in cold storage $\left(4^{\circ} \mathrm{C}\right)$ until use. A second fraction of the rose hip was desiccated in a drying oven, ventilated, thermostatically controlled, operating at $50^{\circ} \mathrm{C} \pm 1^{\circ} \mathrm{C}$ under forced air circulation until constant weight. Afterwards, samples were prepared for phytochemical analysis.

Fruit availability $\left(D_{F}\right)$ was determined according to the following Equation (1):

$$
D_{F}=D_{m} \cdot C_{o}
$$

where: $D_{m}$ was the average availability obtained in 3 plots per site, expressed in $\mathrm{Kg} / \mathrm{m}^{2}$; $C_{o}$ was average coverage of $R$. rubiginosa.

At each site the number of $R$. rubiginosa plants was counted and coverage and height of the plants was obtained to determine density and coverage. Plant density (D) was determined as the number of plants per area (ha). Coverage $\left(C_{o}\right)$ was estimated measuring the diameter of projection of the plant on soil, determining the covered surface by measuring two diameters in a cross. 
With the aim to estimate the content of ascorbic acid (vitamin C) in $R$. rubiginosa rosehips, periodic harvests were performed during year 2010 according to the following schedule: sample 1 (M1) —day 1, first week of March; sample 2 (M2)—day 8; sample 3 (M3)—day 28; sample 4 (M4)—day 48; sample 5 (M5)—day 68; sample 6 (M6)—day 98, during the maturation period (March-June 2010).

In a separate way, 0.5 to $1 \mathrm{~kg}$ of rose hips were collected from 10 randomly selected plants at the two experimental sites during 2011 period. Aliquots from each collected sample were separated to measure the rose hips (length and diameter). Samples were weighted, then desiccated at $50^{\circ} \mathrm{C} \pm 11^{\circ} \mathrm{C}$ until constant weight as indicated. Total soluble solids were estimated in wet rosehip fruits.

\subsection{Determination of Ascorbic Acid Content in Rosehip Fruits}

The content of L-ascorbic acid (Vitamin C) in a specific sample of biological origin is highly conditioned by factors such as maturity, growth conditions of the plant, fruit processing after harvest, time of consumption, among others.

Vitamin $\mathrm{C}$ content was determined by the titrimetric method which relies on the reduction of 2-6-dichlorophenol-indophenol (DCFI) by ascorbic acid [24]. Extracts were obtained from samples $(20 \mathrm{~g})$ of rose hips without seeds, homogeneized in $100 \mathrm{ml}$ of distilled water. The homogenate was centrifuged $(2500 \times \mathrm{g}, 15 \mathrm{~min})$ and $10 \mathrm{ml}$ supernatant was recovered. The solution was deproteinized by addition of $4 \mathrm{~g}$ of trichloroacetic acid in a final volume of $100 \mathrm{ml}$. The extraction solution was filtered and used immediately. The capacity of an extract from biological sample to reduce a standard solution of the dye, determined by titration is directly proportional to the content of ascorbic acid. Dosage of ascorbic acid was made by using as reference a standard solution of pure ascorbic acid, previously validated with iodide [24].

\subsection{Determination of Total Soluble Solids}

Fresh fruits (10 g) were picked at random from each sample and its ends and seeds eliminated. The flesh obtained was homogenized with distilled water until $80 \mathrm{~g}$ and then filtered. The content of soluble solids was determined in three different aliquots from each solution, by using a refractometer ABBE RL3 PZO. The refraction index obtained was expressed as percentage of soluble solids, referred as ${ }^{\circ}$ Brix. The standard unit used to express soluble solids is the ${ }^{\circ}$ Brix, which is defined as the refraction due to a solution of $1 \mathrm{~g}$ of sacarose per $100 \mathrm{~g}$ solution.

\subsection{Determination of Mineral Elements in Rose Hips}

The concentration of mineral elements was determined in $R$. rubiginosa dry rose hips by using an inductively coupled plasma optical emission spectrometry (ICP-OES), (BAIRD ICP 2070).

Rose hips were desiccated as indicated above, seeds were separated and fruits were grounded to powder. Samples were put into a burning cup and $\mathrm{H}_{2} \mathrm{O}_{2}+\mathrm{HNO}_{3}$ were added. The samples were incinerated in a microwave oven. Solubilized samples were 
analyzed with BAIRD ICP 2070 equipment, by ICP-OES.

The concentration of mineral elements in the different samples was obtained by comparison with standard solutions of known concentration, for each one of the analyzed elements: $\mathrm{Al}, \mathrm{Ba}, \mathrm{Bi}, \mathrm{Ca}, \mathrm{Co}, \mathrm{Cu}, \mathrm{Fe}, \mathrm{K}, \mathrm{Mg}, \mathrm{Mn}, \mathrm{Ni}, \mathrm{Pb}, \mathrm{Ti}, \mathrm{Zn}$.

\subsection{Statistical Analysis}

The results were statistically evaluated by using the Statgraphics plus program. Data distribution was fit and the Mann-Whitney W test was used for median comparisons. The standardized skewness and standardized kurtosis, which can be used to determine whether the samples come from normal distributions, were applied to compare standard deviations.

\section{Results}

The habitat preferences of $R$. rubiginosa, have been described by Bran et al. [14] and Damascos and Gallopin [25]. R. rubiginosa prefers loam soils and a humid to subhumid rainfall regime and is associated mainly with disturbed environment, with higher abundance in the vicinity of populated areas or transit corridors.

The study areas (PF-V and EG) are moderately disturbed environments, a woodland of anthropic use for activities such as cattle breeding, agriculture and tourism. In the areas under study, all the requirements for the development of $R$. rubiginosa proposed previously [14] [25] are accomplished.

A scattered presence of $R$. rubiginosa is observed in the village of Potrero de los Funes, with low frequency in the remaining woodland fragments, particularly in the low foothills. It occurs most abundantly on the roadside of the provincial road $n^{\circ} 18$, between Potrero de los Funes and El Volcán (experimental site 1). The density observed in the experimental site 1 was 70 plants/ha, with an average coverage of $2.9 \mathrm{~m}$. Higher density was observed in the populated areas of the tourist village El Volcán as compared to the presence of rose species observed in Potrero de los Funes.

$R$. rubiginosa was present in water gaps in the forest and the sides of the gravel road between El Volcán and Estancia Grande (EG site). It occurs in small patches, particularly in areas with grazing cattle. The density observed in the experimental site 2 was 50 plants/ha, with an average coverage of $2.59 \mathrm{~m}$.

\subsection{Rose Hips Availability of $R$, rubiginosa}

Table 1 shows the fresh weight of rose hip fruits harvested at the two experimental sites (PF-V and EG) during the maturation period (March-June). Comparison of the medians by using the Mann-Whitney W-test for rose hips samples harvested during the same period at the two experimental sites evidenced that there is not a statistically significant difference between the medians ( $95 \%$ confidence level $\mathrm{P} \geq 0.05$ ). Similarly, not statistically significant difference between the medians of the weight of rose hips harvested during different periods (March to June), ( $\mathrm{P} \geq 0.05$; $95 \%$ confidence) was observed by the $\mathrm{W}$ test. 
Table 1. Fruit availability from $R$. rubiginosa, harvested in March and June at the two experimental sites: Potrero de los Funes-El Volcán (PF-V) and Estancia Grande (EG).

\begin{tabular}{|c|c|c|c|c|}
\hline Experimental site & Sample $\mathrm{N}^{\circ}$ & Geographical location & March harvest $\mathrm{t}^{\mathrm{a}}$ & June harvest ${ }^{\mathrm{a}}$ \\
\hline PF-V & $\mathrm{C} 1$ & $\begin{array}{l}33^{\circ} 14^{\prime} 21.0^{\prime \prime} \mathrm{S} \\
66^{\circ} 11^{\prime} 2.4^{\prime \prime} \mathrm{W}\end{array}$ & 0.585 & 0.374 \\
\hline PF-V & $\mathrm{C} 2$ & $\begin{array}{l}33^{\circ} 14^{\prime} 21.5^{\prime \prime} \mathrm{S} \\
66^{\circ} 11^{\prime} 2.5^{\prime \prime} \mathrm{W}\end{array}$ & 0.699 & 0.556 \\
\hline PF-V & $\mathrm{C} 3$ & $\begin{array}{l}33^{\circ} 14^{\prime} 22.5^{\prime \prime S} \\
66^{\circ} 10^{\prime} 57.5^{\prime \prime} \mathrm{W}\end{array}$ & 0.711 & 0.483 \\
\hline EG & $\mathrm{C} 4$ & $\begin{array}{c}33^{\circ} 13^{\prime} 32^{\prime \prime S} \\
66^{\circ} 10^{\prime} 33.3^{\prime \prime} \mathrm{W}\end{array}$ & 0.655 & 0.504 \\
\hline EG & $\mathrm{C} 5$ & $\begin{array}{c}33^{\circ} 13^{\prime} 29.7^{\prime \prime} \mathrm{S} \\
66^{\circ} 10^{\prime} 36.4^{\prime \prime} \mathrm{W}\end{array}$ & 0.524 & 0.575 \\
\hline EG & $\mathrm{C} 6$ & $\begin{array}{c}33^{\circ} 13^{\prime} 28.7^{\prime \prime S} \\
66^{\circ} 10^{\prime} 35.6^{\prime \prime} \mathrm{W}\end{array}$ & 0.590 & 0.560 \\
\hline
\end{tabular}

${ }^{\mathrm{a}}$ Fresh weight $(\mathrm{kg})$.

The average availability of fresh fruits $(\mathrm{Dm})$ obtained considering three plants of $R$. rubiginosa for each experimental site estimated in March was $0.665 \mathrm{~kg} / \mathrm{m}^{2}$ and 0.590 $\mathrm{kg} / \mathrm{m}^{2}$ for PF-V and EG, respectively. During June, the estimated Dm was $0.471 \mathrm{~kg} / \mathrm{m}^{2}$ and $0.546 \mathrm{~kg} / \mathrm{m}^{2}$ for PF-V and EG, respectively. Besides, fruit availability $\left(D_{F}\right)$ was estimated considering Dm relative to the medium/plant covered total area, as indicated. Rose hip fruits availability $\left(D_{F}\right)$ during March was $4.39 \mathrm{~kg}$ and $3.10 \mathrm{~kg}$ for PF-V and EG, respectively, and $3.11 \mathrm{~kg}$ and $2.87 \mathrm{~kg}$ for PF-V and EG, respectively for the late harvest of June.

Table 2 shows the median values (Me), standard deviation (SD) of the W statistic for the length and diameter of harvested rose hips. The length of the rose hips varied between 1.57 to $2.10 \mathrm{~cm}$ and 1.54 to $2.00 \mathrm{~cm}$ for PF-V and EG respectively, and comparison of the median by $\mathrm{W}$ test indicates no statistically significant difference between the two sites. The diameter of the rose hips ranged from 1.13 to $1.45 \mathrm{~cm}$ for PF-V and from 1.05 to $1.30 \mathrm{~cm}$ for EG sites. Comparison of the median according $\mathrm{W}$ test indicates statistically significant difference between the two sites.

\subsection{Ascorbic Acid Content in Rose Hips of $R$. rubiginosa}

For assessment of L-ascorbic acid content, sample C1 collected in PF-V was used as a control. The fresh and dried rose hip fruits showed a $\mathrm{pH}$ of 3 and 4, for PF-V and EG, respectively. The ascorbic acid content of rose hips showed an increase during the maturation period in both sites, reaching a pick between the late April and early May. In fresh rose hip fruits, the content of L-ascorbic acid varied in a range of 1040 to 1770 $\mathrm{mg} / 100 \mathrm{~g}$ and $1410-1770 \mathrm{mg} / 100 \mathrm{~g}$ for PF-V and EG, respectively. In dried rose hip fruits, it varied in a range of 210 to $360 \mathrm{mg} / 100 \mathrm{~g}$ and 230 to $360 \mathrm{mg} / 100 \mathrm{~g}$ and PF-V and EG, respectively. Thus, a decrease in the ascorbic acid content of $75 \%-85 \%$ was observed in dried rose hip fruits. Comparison of the medians by using the Mann-Whitney 
Table 2. Medians (Me), standard deviation (SD) and $\mathrm{W}$ statistics values for the length and diameter of rose hip fruits.

\begin{tabular}{ccccccc}
\hline Variable & Site & $\mathrm{n}$ & $\mathrm{Me}$ & $\mathrm{SD}$ & $\mathrm{W}$ & P value \\
\hline Lenght & PF-V & $(\mathrm{n}=20)$ & 1.82 & 0.18 & 170 & 0.5082 \\
& EG & $(\mathrm{n}=10)$ & 1.83 & 0.13 & & \\
\multirow{2}{*}{ Diameter } & PF-V & $(\mathrm{n}=20)$ & 1.32 & 0.10 & 236 & 0.0003 \\
& EG & $(\mathrm{n}=10)$ & 1.14 & 0.06 & & \\
\hline
\end{tabular}

$\mathrm{W}$ test for the content of ascorbic acid in either fresh or dried rose hip, showed not statistically significant difference between samples in the two experimental sites $(P \geq 0.05$; 95\% confidence). However, the $\mathrm{W}$ test showed that there is statistically significant difference between the medians of ascorbic acid content in fresh and dry rose hips analyzing each particular site (PF-V or EG), ( $<<0.05$; 95\% confidence). The ascorbic acid content in fresh and dried rose hips expressed in grams of vitamin $\mathrm{C} / 100 \mathrm{~g}$ of fruit, was plotted for the PF-V site (Figure 1), and the EG site (Figure 2), as well as the polynomial fit.

\subsection{Soluble Solid Content in Rose Hip Fruits}

Total soluble solids in fresh rose hips showed a variation between 32.55 to $55.20{ }^{\circ} \mathrm{Brix}$ for PF-V site and 34.56 to $50.48{ }^{\circ}$ Brix for EG site. Comparison of the medians with W test evidenced a statistically significant difference between the two sites $(\mathrm{P}<0.05 ; 95 \%$ confidence).

To quantify the loss of weight after desiccation at $50^{\circ} \mathrm{C} \pm 1{ }^{\circ} \mathrm{C}$ until constant weight, rose hips aliquots $(100 \mathrm{~g})$ of each sample were evaluated: a percentage of 36.19 and $39.72 \%$ loss of weight for PF-V and EG was observed, respectively. Using $\mathrm{W}$ test to compare the medians, a statistically significant difference between the two sites $(\mathrm{P}<$ $0.05 ; 95 \%$ confidence) was observed.

\subsection{Mineral Content in Rose Hips of $R$. rubiginosa}

In order to make a comparative analysis between data from San Luis province with other sites, samples from Andacollo-La Primavera (A-LP) in the province of Neuquén were included for evaluation of mineral content. Table 3 shows the results of determination by ICP-OES of the concentrations of mineral present in samples from rose hips. Measurements were performed with 14 elements but concentrations of $\mathrm{Bi}, \mathrm{Co}, \mathrm{Ni}$ and $\mathrm{Pb}$ were very low or undetectable in some of the samples from the three experimental sites considered, PF-V, EG and A-LP.

Calcium contents varied between $654.9-8169.94 \mathrm{ppm}$ for the different experimental sites evaluated. Surprisingly, the lower and the higher content were in samples from San Luis province, where similar soil and climate conditions are given. PF-V site showed closest values to those reported for Neuquén (15,433 - 11,387 ppm) [16].

The content of K element in rose hip fruits ranged from 24,459 - 23,095.4 ppm, similar to values reported by Damascos et al. [16] for two sites in Neuquén (27,000 - 


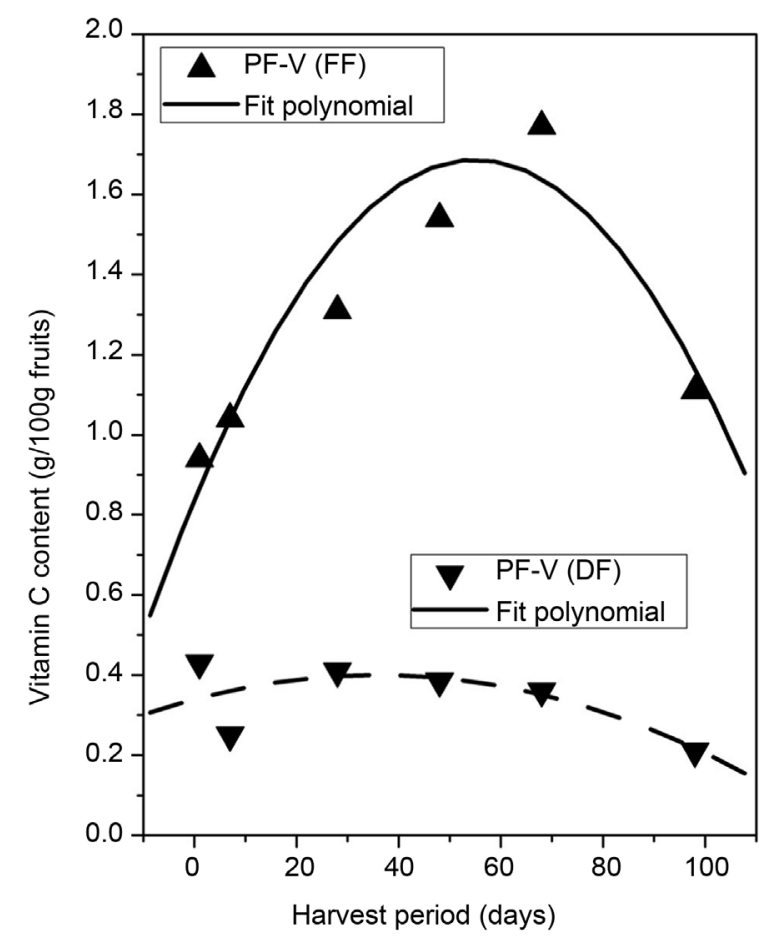

Figure 1. Ascorbic acid content in rose hip fresh fruits (FF) and rose hip dried fruits (DF) for experimental site Potrero de los Funes-El Volcán (PF-V).

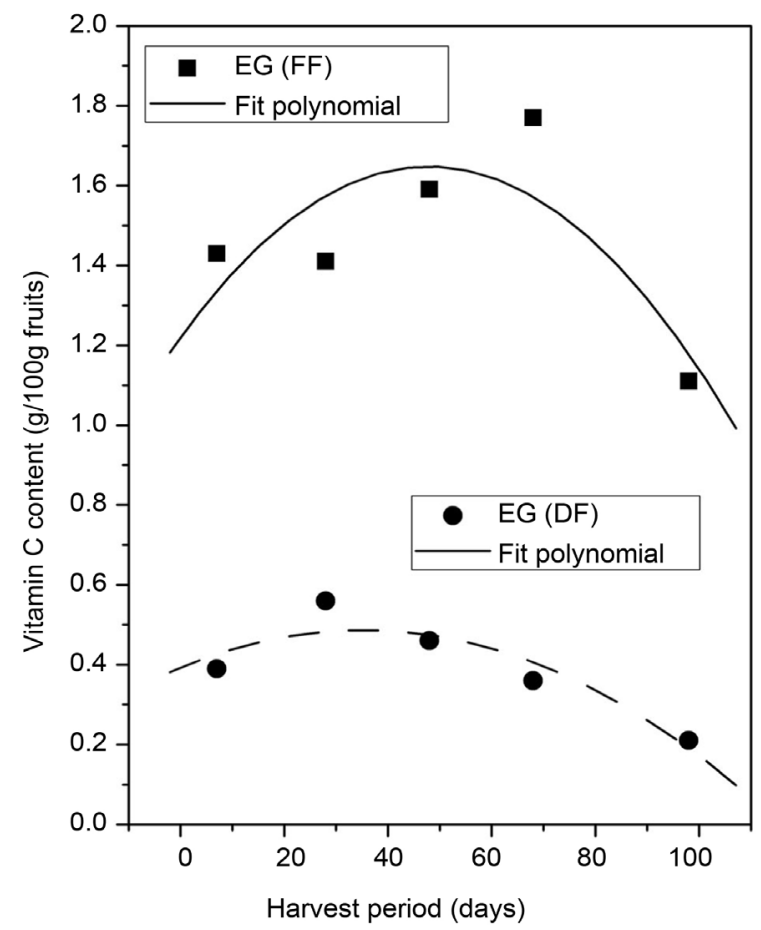

Figure 2. Ascorbic acid content in rose hip fresh fruits (FF) and rose hip dried fruits (DF) for experimental site Estancia Grande (EG). 
Table 3. Comparative table for the mineral element contents in $R$. rubiginosa rose hips obtained by ICP-COES at three experimental sites PF-V, EG y A-LP.

\begin{tabular}{cccc}
\hline Site & PF-V & EG & A-LP \\
\hline Element & 40.09 & Values expressed in ppm ${ }^{\mathrm{b}}$ & \\
\hline $\mathrm{Al}$ & 8.42 & 70.96 & 73.49 \\
$\mathrm{Ba}$ & $*$ & 8.75 & 18.37 \\
$\mathrm{Bi}$ & 8169.94 & & 5180.78 \\
$\mathrm{Ca}$ & $*$ & 654.9 & \\
$\mathrm{Co}$ & 1.002 & & 6.246 \\
$\mathrm{Cu}$ & 4.46 & 1.216 & 39.035 \\
$\mathrm{Fe}$ & $23,095.4$ & 1.35 & 1579.95 \\
$\mathrm{~K}$ & 2012.83 & $24,459.9$ & 19.41 \\
$\mathrm{Mg}$ & 29.73 & 1790.01 & 6.886 \\
$\mathrm{Mn}$ & $*$ & 29.39 & \\
$\mathrm{Ni}$ & $*$ & & 11.658 \\
$\mathrm{~Pb}$ & 0.892 & 7.77 & \\
$\mathrm{Ti}$ & 6.68 & & \\
$\mathrm{Zn}$ & & & \\
\hline
\end{tabular}

${ }^{b}$ Undetected element, values could be below the detection level.

19,933.33 ppm). The content of Fe observed ranged from 1.35 to $4.46 \mathrm{ppm}$ for EG and $\mathrm{PF}-\mathrm{V}$ sites in San Luis province, comparatively lower than those observed in various sites in Neuquén province, where values of $21.3 \mathrm{ppm}$ have been reported [16]. The experimental site A-LP, located in Neuquén province showed a higher content of $\mathrm{Fe}$, $39.035 \mathrm{ppm}$. A relatively high content of $\mathrm{Ni}$ and $\mathrm{Cu}$ was observed in ALP, while the content of Ti was below the detection levels.

Magnesium content in rose hips varied between 2012.83 and $1790.01 \mathrm{ppm}$ for PF-V and EG sites respectively, while an intermediate value for A-LP (1579.95) was observed. Manganese content was similar at the three experimental sites compared ranged from 1579.95 (A-LP) to 2012.83 .

The content of $\mathrm{Ba}$ was $8.75 \mathrm{ppm}$ and $8.42 \mathrm{ppm}$ for $\mathrm{PF}-\mathrm{V}$ and $\mathrm{EG}$, respectively, while a higher value was observed at the site A-LP (18.37 ppm). Similarly, Damascos et al. [16] reported quite different values 8.27 and 31.27 ppm for two sites in Neuquén province.

Regarding $\mathrm{Zn}$ content, the determined values were $7.77 \mathrm{ppm}$ for PF-V $6.68 \mathrm{ppm}$ for EG and $11.658 \mathrm{ppm}$ for A-LP. The content of $\mathrm{Zn}$ observed in this study fall within the range reported for sites in Neuquén (7.94 - 5.97) [16].

\section{Discussion}

Unconventional resources such as Non-Timber Forest Products increase the food supply, representing new sources of vitamins and minerals. $R$. rubiginosa is considered an NTFP by FAO, as some of its products are relevant to the rural economy, complementing traditional agricultural production with the supply of products for food and 
health care.

The aim of this study was to estimate the availability of rose hip fruits of $R$. rubiginosa growing in hilly environments of central San Luis province. We evaluate fruit availability, phytochemical characteristics such as ascorbic acid (vitamin C) content, soluble solids and minerals elements in this species introduced in Argentina. For sample collection Rosa rubiginosa plants were selected at two experimental sites in the Chaco Serrano Ecoregion of the Province of San Luis, Argentina: PF-V (Potrero de los Funes-El Volcán) and EG (Estancia Grande).

\subsection{Rose Hips Availability of $R$, rubiginosa}

Rose hips of $R$. rubiginosa have a long maturation period (March to June), and can be harvested at different times. The average production observed was higher at the beginning harvest period for both sites (PF-V and EG) than during June. The present data are comparable to those obtained by Bran et al. [2] [14] in plots covered entirely by rosehip (100\% coverage). The authors reported for the province of Neuquén values of $0.81 \mathrm{~kg} / \mathrm{m}^{2}$ for Pilo Lil and $1.40 \mathrm{~kg} / \mathrm{m}^{2}$ for Lipela in crops from 26 March to 16 April. The lower rose hips harvest values observed in the present study during June might be due to two causes, decreased hydration of rose hips and rose hips consumption mainly by wild and domestic animals.

\subsection{Ascorbic Acid Content in Rose Hips of R. rubiginosa}

The variation of vitamin C content in fresh rose hips was $1040-1770 \mathrm{mg} / 100 \mathrm{~g}$, similar to that reported by other authors for the genus Rosa. Pirone et al. [7] reported for $R$. eglanteria in Río Negro, Argentina, vitamin C content of $500-2200 \mathrm{mg} / 100 \mathrm{~g}$ in fresh rose hips. Demir and Özcan [11] reported for Rosa canina a range between 2365 - 2712 $\mathrm{mg} / 100 \mathrm{~g}$ of fresh rose hips. Ercisli [26] reported for R. dumalis, R. canine, R. villosa and $R$. pisiformis, a range of $727-943 \mathrm{mg} / 100 \mathrm{ml}$, ranging from 300 to $4000 \mathrm{mg} / 100 \mathrm{~g}$ of rose hip fruits. Cunja et al. [9] reported for Rosa canina a Vitamin C content of $935 \mathrm{mg} / 100 \mathrm{~g}$ of $\mathrm{dw}$ at midpoint of the ripening period. The values obtained in the present study are higher than those reported by Nadpal et al. [8] between 0.56 and $3.73 \mathrm{mg} / \mathrm{g}$ of dw Rosa species of Serbia. Variation in the observed values can be attributed to differences in the maturity stage of the fruits, environmental conditions, geographic origin and genetic variation.

Rose hips of $R$. rubiginosa are used fresh in various ways (sweets, jellies, liquors, etc.) but mostly are dehydrated to preserve them and export them. The results obtained show that there is an increase in the vitamin $\mathrm{C}$ content in fresh fruits, reaching a plateau in late April, early May. Thus, it follows that this would be the optimum period of fruit harvest. A lower content of vitamin $\mathrm{C}$ was observed in dry rose hips.

According to Chamorro and Fernández Heredia [24] ascorbic acid, in aqueous solution at $\mathrm{pH}$ lower than 7.6 is not oxidized when exposed to air, unless there were traces of copper or other materials which catalyze the reaction. On the other hand, ascorbic acid degradation or catalyzed oxidative pathway are influenced by the presence of oxy- 
gen and metal ions such as $\mathrm{Fe}^{3+}$ and $\mathrm{Cu}^{2+}$, which accelerate the reaction rates [27]. Whereas fresh rose hips have a $\mathrm{pH} 3$ and traces of $\mathrm{Cu}$ and $\mathrm{Fe}$, the presence of these metals may be responsible for the lower concentration of ascorbic acid in mature fruits harvested at the end of the ripening period (June) compared with the ascorbic acid values measured for late April early May.

Since a significant amount of rose hips is used in dried form (for infusions, soups and cream base yugourt, etc.) the ascorbic acid content was evaluated in dehydrated fruits. Dehydration produces changes in fresh product, both edible and organoleptic quality and nutritional value of food [7]. Particularly ascorbic acid content is very sensitive to various forms of processes (temperature, salt and sugar concentration, $\mathrm{pH}$, oxygen, enzymes, the initial concentration of the acid and the ascorbic/dehydroascorbic acid ratio) [9]. These factors are associated with the dehydration process used and the phytochemical composition of rose hips. Dehydroascorbic acid has considerable antiscorbutic activity, since it is easily reduced to ascorbic acid in the animal body.

In this study, the dehydration process was in an oven at $50^{\circ} \mathrm{C}$ under hot air stream until constant weight, which ensures that enzymes are not degraded since the activation energy of ascorbic acid degradation is between $60^{\circ} \mathrm{C}$ and $90^{\circ} \mathrm{C}$ [7]. According to Ochoa et al. [28], for $R$. rubiginosa rose hips the only variable that influences the drying rate is temperature. Ascorbic acid content in dehydrated rose hip fruits was highly reduced, as compared to that of fresh rose hip fruits. Our results indicate that the values of ascorbic acid content obtained in dehydrated rose hips are influenced by the moisture content and ascorbic acid in the sample, which were taken at different maturation times.

Since the dried crystals of ascorbic acid are not altered by the action of air and sunlight, the dehydrated rose hips may be stored longer [24]. Moreover, $\mathrm{pH} 4$ was observed in dried rose hips, $\mathrm{pH}$ at which dehydroascorbic acid is fairly stable, so as in fresh rose hips the lowest concentration of ascorbic acid content could be due to the instability of $\mathrm{L}$-ascorbic acid and/or oxidation since metal ions such as $\mathrm{Fe}$ and $\mathrm{Cu}$ are present.

\subsection{Soluble Solid Content in Rose Hip Fruits}

Changes related to the maturity of rose hips include increased total soluble solids (SST), total sugars, $\mathrm{pH}$ and others. Our results indicate that the content of SST, in fresh rose hip fruit varies in a range between 32.55 and $55.20^{\circ}$ Brix, higher than the values reported by Uggla et al. [29] for $R$. rubiginosa rose hips during maturation within a range from 13.1 to $25.7^{\circ}$ Brix. Balta et al. [30] reported SST values for the genus of $22-40$ ${ }^{\circ}$ Brix and Cunja et al. [9] reported a total sugar content of $25.9-48.0 \mathrm{mg} / 100 \mathrm{~g} \mathrm{dw}$. The observed difference in values might be due to conditions such as the incidence of light on the plant, the degree of maturity, time and manner of fruit harvest.

\subsection{Mineral Content in Rose Hips of R. rubiginosa}

The content of minerals elements (traces) is important and of great interest because of the use of rose hips of $R$. rubiginosa as food or dietary supplement. Damascos et al. [16] determined the mineral content in fruits of six wild species, including $R$. rubiginosa, 
highlighting the presence of minerals such as $\mathrm{Fe}, \mathrm{Ca}$ and $\mathrm{K}$ in significant quantities for human health. For comparison, we evaluated the mineral content of rose hips in two experiment sites PF-V and EG in San Luis province, plus A-LP, in Neuquén province, Argentina.

The content of minerals elements such as $\mathrm{K}, \mathrm{Ba}$ and $\mathrm{Zn}$ observed in rosehip fruits at the experimental sites PF-V and EG in San Luis province were similar to those obtained in A-LP in Neuquén province and those reported by Damascos et al. [16]. Türkben et al. [31] informed lower values of K content, for samples from Turkey (1639.10 ppm).

The values of $\mathrm{Ca}$ and $\mathrm{Mg}$ evaluated in this study are similar to those reported by Türkben et al. [31] determined by the same method in dry fruits of Rosa canina being Mg (1358.67) and Ca (4989.33). Calcium and Potassium content appeared as highly variable when compared with previous reports [11] [16] [31] [32]. Soil quality might be the cause of this variation. The content of $\mathrm{K}$ observed in samples from PF-V and EG were comparable to those reported by Damascos et al. [16] in Neuquén province and higher than data from Turkey [11] [32].

The content of Fe observed was lower in samples from San Luis province and high in A-LP, Neuquén, being highly variable depending on the experimental site for fruit collection [11] [16] [32].

Although some of the minerals elements evaluated such as $\mathrm{K}, \mathrm{Ba}, \mathrm{Zn}$ exhibited similar values among the sites studied in San Luis when compared with sites of Neuquén, in other elements such as $\mathrm{Ca}$ and $\mathrm{Fe}$ we found differences among the sites evaluated. These data were expected since we evaluated the minerals elements in the same species growing in different geographical locations. Other authors [16] [26] evaluated different species growing in the same geographic site. Evaluation of the mineral composition in some species of the genus Rosa [26] [33] [34] detected differences between species in their content. Our results provide evidence in agreement with Ercisli's [26] proposal who pointed out that the mineral composition of the rose hip fruits depend not only on the species or variety, but also the environment in which develops, soil characteristics and climatic conditions.

Regarding the mineral content, we should emphasize the presence of minerals such as calcium, iron and potassium in significant quantities to human health. Dry fruits maintain a high level of vitamin content, a characteristic added to the content of minerals elements. Particularly calcium content is important for adults with digestive problems to consumption of milk, providing an additional nutritional value to rose hips of $R$. rubiginosa. Thus, ingestion of rose hips in different forms could supply part of the Ca needed by humans (the recommended daily intake is 800 to $1200 \mathrm{mg}$, depending on age).

In summary, these results show a variation of vitamin $C$ during the harvest period, with high content in dried rose hip fruits. On the other hand, scientifically validate the presence of metabolites of pharmacological application in fruits of $R$. rubiginosa, which, together with the content of different mineral elements, reinforce the popular knowledge and cultural use of the rose hips as food and medicinal resources. 


\section{Conclusion}

This paper provides information on the vitamin C content of rose hip fruits and minerals elements of $R$. rubiginosa (NTFP) in the central area of the province of San Luis. The importance of this unconventional product is due to the content of ascorbic acid and dehydroascorbic acid. The second one also has considerable antiscorbutic activity, as is readily reduced to ascorbic acid in animal organisms. Dry rosehip fruits maintain a high level of ascorbic acid content. The high content of minerals elements, particularly calcium, becomes valuable for adults with digestive problems to the consumption of milk. Taken together, the high content of Vitamin C and minerals elements confers an important nutritional value to fruits of $R$. rubiginosa.

\section{Acknowledgements}

Aguirre, GU has fellowship from CONICET (Consejo Nacional de Investigaciones Científicas y Tecnológicas, Argentina). G. M. Ciuffo is a member of the researcher's career of CONICET. This work was supported by grants from Universidad Nacional de San Luis, Argentina.

\section{References}

[1] Vavra, M., Parks, C.G. and Wisdom, M.J. (2007) Biodiversity, Exotic Plant Species, and Herbivory: The Good, the Bad, and the Ungulate. Forest Ecology and Management, 246, 66-72. https:/doi.org/10.1016/j.foreco.2007.03.051

[2] Bran, D., Damascos, M., López, C., Ayesa, J., Umaña, F. and Moraga, H. (2004) Distribución, Abundancia y Disponibilidad de Frutos de Rosa Mosqueta en la Provincia de Neuquén. Patagonia Forestal, 10, 6-8.

[3] Chandrasekharan, C., Frisk, T. and Roasio, J.C. (1996) Desarrollo de productos forestales no madereros en América Latina y El Caribe. Dirección de Productos Forestales, FAO.

[4] Solomon, T., Welu, G. and Tajebe, L. (2014) Resource Potential of Non Timber Forest Products in Dawro Zone, South Ethiopia. Journal of Biology, Agriculture and Healthcare, 4, 169-173.

[5] FAO (2007) Situación de los bosques del mundo 2007. Organización de las Naciones Unidas para la Agricultura y la Alimentación, Roma. http://www.fao.org/docrep/009/a0773s/a0773s00.HTM

[6] Ladio, A. (2005) Malezas exóticas comestibles y medicinales utilizadas en poblaciones del Noroeste patagónico: Aspectos etnobotánicos y ecológicos. Boletín Latinoamericano y del Caribe de Plantas Medicinales y aromáTicas, 4, 75-80.

[7] Pirone, B.N., Ochoa, M.R., Kesseler, A.G. and De Michelis, A. (2007) Chemical Characterization and Evolution of Ascorbic Acid Concentration During Dehydration of Rosehip (Rosa eglanterid) Fruits. American Journal of Food Technology, 2, 377-387. https:/doi.org/10.3923/ajft.2007.377.387

[8] Nađpal, J.D., Lesjak, M.M., Šibul, F.S., Anačkov, G.T., Četojević-Simin, D.D., MimicaDukić, N.M. and Beara, I.N. (2016) Comparative Study of Biological Activities and Phytochemical Composition of Two Rose Hips and Their Preserves: Rosa canina L. and Rosa arvensis Huds. Food Chemistry, 192, 907-914. https:/doi.org/10.1016/j.foodchem.2015.07.089

[9] Cunja, V., Mikulic-Petkovsek, M., Zupan, A., Stampar, F. and Schmitzer, V. (2015) Frost 
Decreases Content of Sugars, Ascorbic Acid and Some Quercetin Glycosides but Stimulates Selected Carotenes in Rosa canina Hips. Journal of Plant Physiology, 178, 55-63.

https:/doi.org/10.1016/j.jplph.2015.01.014

[10] Espinoza, T., Valencia, E., Quevedo, R. and Díaz, O. (2016) Physical and Chemical Properties Importance of Rose Hip ( $R$. canina, R. rubiginosa): A Review. Scientia Agropecuaria, 7, 67-78. https:/doi.org/10.17268/sci.agropecu.2016.01.07

[11] Demir, F. and Özcan, M. (2001) Chemical and Technological Properties of Rose (Rosa canina L.) Fruits Grown Wild in Turkey. Journal of Food Engineering, 47, 333-336. https:/doi.org/10.1016/S0260-8774(00)00129-1

[12] Moure, A., Franco, D., Sineiro, J., Domínguez, H., Núñez, M.J. and Lema, J.M. (2001) Antioxidant Activity of Extracts from Gevuina avellana and Rosa rubiginosa Defatted Seeds. Food Research International, 34, 103-109. https:/doi.org/10.1016/S0963-9969(00)00136-8

[13] Valladares, J., Palma, M., Sandoval, C. and Caravajal, F. (1996) Crema de aceite de mosqueta (Rosa aff. rubiginosa L.) II. Parte: Estudio de las propiedades físico-químicas de estabilidad, eficacia, cosmética y aplicación sistemática en clínica. Anales de la Real Academia de Farmacia, 51, 597-612.

[14] Bran, D., Damascos, M., López, C., Ayesa, J., Umaña, F. and Moraga, H. (2003) Distribución, Abundancia y Disponibilidad de Frutos de Rosa Mosqueta en la Provincia de Neuquén. Comunicación Técnica de Relevamiento Integrado No. 85, Instituto Nacional de Tecnología agropecuaria, INTA.

[15] Ladio, A.H. and Rapoport, E.H. (2002) La variación estacional de las plantas silvestres comestibles en baldíos suburbanos de Bariloche, Parque Nacional Nahuel Huapi, Patagonia, Argentina. Vida Silvestre Neotropical, 11, 33-41.

[16] Damascos, M.A., Arribere, M., Svriz, M. and Bran, D. (2008) Fruit Mineral Contents of Six Wild Species of the North Andean Patagonia, Argentina. Biological Trace Element Research, 125, 72-80. https:/doi.org/10.1007/s12011-008-8159-y

[17] Aguirre, G.U., Ciuffo, G.M. and Ciuffo, L.E.C. (2007) Producto forestal no maderero. Rosa rubiginosa (L.), exótica de interés medicinal y comercial. Boletín Latinoamericano y del Caribe de Plantas Medicinales y Aromáticas, 6, 230-231.

[18] Aguirre, G.U., Ciuffo, G.M. and Ciuffo L.E.C. (2008) Potencial adaptativo de Rosa ruginosa L. en dos eco-regiones argentinas. 3 rd Jornadas Nacionales de Flora Nativa-4th Encuentro de Cactáceas, 271-287.

[19] Aguirre, G.U., Ciuffo, G.M. and Ciuffo, L.E. (2009) Genetic Differentiation of Rosa rubiginosa L. in Two Different Argentinean Ecoregions. Plant Systematics and Evolution, 281, 183-192. https:/doi.org/10.1007/s00606-009-0200-x

[20] Torrella, S.A. and Adámoli, J. (2006) Situación ambiental de la ecorregión del chaco seco. In: Brown, A., Martínez Ortiz, U., Acerbi, M. and Corcuera, J., Eds., La Situación Ambiental Argentina 2005, Fundación Vida Silvestre, 75-82.

[21] Borisov, J., Carosio, C. and Ciuffo, L. (1991) Las Comunidades Vegetales de la Cuenca del Lago Potrero de los Funes (San Luis, Argentina) Parodiana, 6, 303-322.

[22] Ojeda, G. (2002) Características geomorfológicas y rasgos erosivos de la cuenca del Arroyo el durazno, Provincia de San Luis, Argentina. Actas del 15th Congreso Geológico Argentino, El Calafate, 23-26 April 2002.

[23] Damascos, M.A. and Bran, D. (2006) Rosa canina (Rosaceae) nueva cita para la flora Argentina. Hickenia, 3, 285-288.

[24] Chamorro, S.G. and Fernández Heredia C. (1969) Ácido L-Ascórbico (Vitamina C) In: Methods of Vitamin Assay, Editorial Academia, León, 265-280. 
[25] Damascos, M.A. and Gallopin, G.G. (1992) Ecología de un arbusto introducido (Rosa rubiginosa L. = Rosa eglanteria L.): Riesgo de invasión y efectos en las comunidades vegetales de la región andino-patagónica de Argentina. Revista Chilena de Historia Natural, 65, 395-407.

[26] Ercisli, S. (2007) Chemical Composition of Fruits in Some Rose (Rosa spp.) Species. Food Chemistry, 104, 1379-1384. https:/doi.org/10.1016/j.foodchem.2007.01.053

[27] Serra, H.M. and Cafaro, T.A. (2007) Ácido ascórbico: Desde la química hasta su crucial función protectiva en ojo. Acta Bioquímica clÍnica Latinoamericana, 41, 9.

[28] Ochoa, M.R., Kesseler, A.G., Pirone, B.N., Márquez, C.A. and De Michelis, A. (2002) Shrinkage during Convective Drying of Whole Rose Hip (Rosa rubiginosa L.) Fruits. LWT_Food Science and Technology, 35, 400-406. https:/doi.org/10.1006/fstl.2001.0861

[29] Uggla, M., Gustavsson, K.E., Olsson, M.E. and Nybom, H. (2005) Changes in Colour and Sugar Content in Rose Hips (Rosa dumalis L. and R. rubiginosa L.) during Ripening. The Journal of Horticultural Science and Biotechnology, 80, 204-208.

https:/doi.org/10.1080/14620316.2005.11511918

[30] Balta, F., Yarilgac, T. And Balta, M.F. (2001) Fruit Characteristics of Native Almond Selections from the Lake Van Region (Eastern Anatolia, Turkey) Journal American Pomological Society, 55, 58-61.

[31] Turkben, C., Uylaser, V., Incedayi, B. and Çelikkol, I. (2010) Effects of Different Maturity Period and Processes on Nutritional Components of Rose Hip (Rosa canina L.) Journal of Food, Agriculture \& Environment, 8, 26-30.

[32] Kazaz, S., Baydar, H. and Erbas, S. (2009) Variation in Chemical Compositions of Rosa damascene Mill. and Rosa canina L. Fruits. Czech Journal of Food Sciences, 27, 178-184.

[33] Botella, M.A., Obón, C., Egea, I., Romojaro, F. and Pretel, M.T. (2007) Propiedades físicoquímicas y antioxidantes de frutos recolectados tradicionalmente en la provincia de Albacete. Acta Horticulturae, 48, 662-665.

[34] Celik, F., Kazankaya, A. and Ercisli, S. (2009) Fruit Characteristics of Some Selected Promising Rose Hip (Rosa spp.) Genotypes from Van Region of Turkey. African Journal of Agricultural Research, 4, 236-240.

Submit or recommend next manuscript to SCIRP and we will provide best service for you:

Accepting pre-submission inquiries through Email, Facebook, LinkedIn, Twitter, etc. A wide selection of journals (inclusive of 9 subjects, more than 200 journals)

Providing 24-hour high-quality service

User-friendly online submission system

Fair and swift peer-review system

Efficient typesetting and proofreading procedure

Display of the result of downloads and visits, as well as the number of cited articles

Maximum dissemination of your research work

Submit your manuscript at: http://papersubmission.scirp.org/

Or contact ajps@scirp.org 